\title{
The effect of students' developing their own digital games on their academic achievement and attitudes towards for English lessons
}

\author{
Kadir Kabak \\ Graduate Student, Necmettin Erbakan University, Konya, Turkey; \\ ORCID: 0000-0002-7747-2909
}

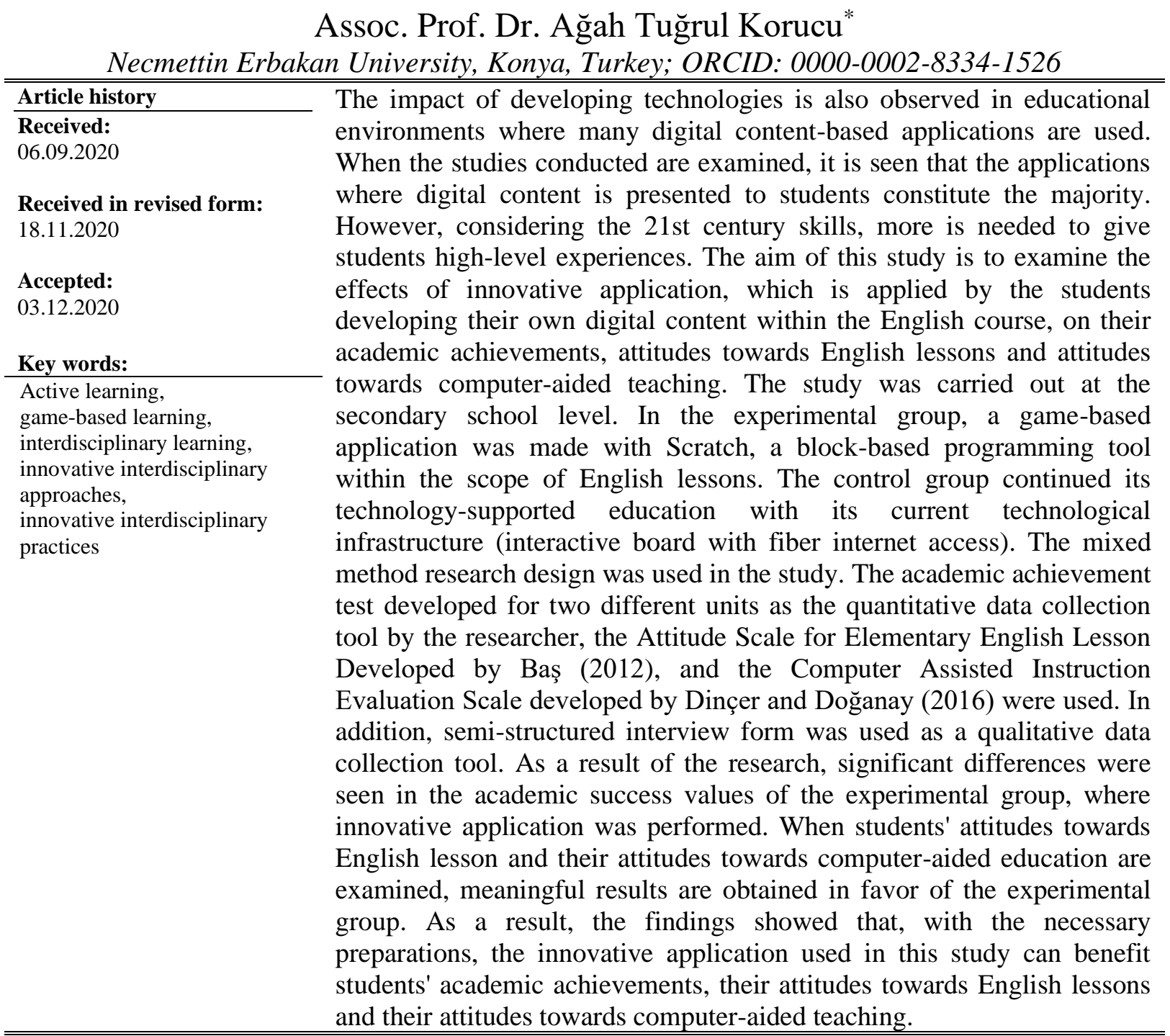




\section{Introduction}

The technology that shapes today's world has also various effects on education systems over time (Taşdemir \& Şüyun, 2016; Yükseltürk \& Altıok, 2016). It is observed that the use of technology in education contributes positively to the education and training experiences of students through different applications created within the scope of many different courses. When the studies conducted within this framework are examined, important findings are encountered in meta-analysis studies. It has been observed that both academic success and attitudes such as motivation and perception give positive results in processes for different courses (Hussein, Ow, Cheong, Thong,\&Ebrahim, 2019; Tokac, Novak, \& Thompson, 2019). Reforms in education systems continue in order to raise individuals who are in line with the needs of the age we are in (Günkör, 2017).

Courville (2011) talked about digital content provided by today's technology. Digital content created with today's technology can offer experiences that students will be active in learning environments. Subrahmanyam and Renukarya (2015) mentioned that digital content should be learning tools. The digital content used is considered successful to the extent which they can achieve the purpose of education.

In the report published by OECD (Economic Cooperation and Development Organization) in 2018, the vision of the education system in Japan in 2030 is mentioned. According to the report, it is stated that the country of Japan will focus on using active learning strategies in the new curriculum, which will be implemented from the 2021-2022 academic year. The objectives of the training have been established within three core competencies. These goals are motivation to learn and turn learning into life, acquisition of knowledge and technical skills, thinking, judgment and self-expression (OECD, 2018).

As assessed by Jennett et al. (2017) in terms of developing digital content of students by using different disciplines, the effectiveness of interdisciplinary applications that are student centered can be observed. In addition, developing a digital content can provide positive developments in values such as responsibility development and belonging.

In the study conducted by Akpinar and Altun (2014), there are studies showing that one of the methods that should be used in reaching 21st century skills is teaching computer programming. Considering the work of designing content with game engines at the vocational high school level Alan's (2017) work to endear programming lesson, designing digital content with block-based programming tool can be demonstrated within the scope of programming teaching. When studies on innovative interdisciplinary practices are examined, it is observed that the aim of gaining 21 st century skill is a common goal in this framework.

In educational settings, play is an important source of motivation in the learning process rather than traditional teacher-centered understanding (Prensky, 2003; Whelan, 2005). Nowadays, game-based learning applications are widely implemented in the form of game applications with digital content. Learning with digital content significantly represents gamebased learning today.

Huizenga, Admiraal, Ten Dam, and Voogt (2019) stated that teachers can continue their teaching outside the classroom thanks to mobile-based games. They stated that student behavior is important in the game process and that the desire to win the game may have negative results in terms of learning. Chen, Liu, and Shou (2018) stated that students who did 
not compete during the study showed higher success compared to students who competed with each other (although there was no significant difference between the results). However, he stated that it is necessary to test the effects of the competitive factor in reaching the purpose of the training process with more research.

It is important to organize the learning process in educational institutions with the understanding of solving real life problems by living (Gülbahar, Avc1,\& Kalayc1, 2012). This situation is met in many ways thanks to computer aided educational environments. Scholz (2016) talks about the effectiveness of language learning with computer aided gaming applications. In his study, he stated that games play an important role in child development and can enable children to learn by having fun.

In education and training environments where block-based programming tools are used as a game, experiences that attract the attention of individuals of all ages and increase learning motivation can be obtained (Glushkova, 2016). Together with their logical and algorithmic thinking skills, these environments can also provide individuals with positive experiences in solving real-life problems. These tools can provide a useful experience in educational and training environments according to the game-based learning approach.

When many studies conducted to date are examined, applications where digital content is presented to children are widely seen. The data obtained in these studies give positive results in terms of academic achievements and attitudes. However, in the literature, the studies conducted in the way that students designed their educational digital content are not sufficient in number. Controlling the effects of such an experience on academic achievement and attitudes can contribute to the literature.

\section{Purpose of the research}

In this research, it is aimed that the students have a positive experience both in designing their own product and in achieving the achievements within the existing lesson unit while designing this product. In this study, "What are the effects of students' efforts to develop their own digital games on their academic achievements and attitudes towards the course?" was asked to be further investigated. Within the framework of this question, answers to the following questions were also sought:

(1) Is there a significant difference in terms of academic success between the experimental group students who carried out the digital game development study and the control group students who continued the traditional method?

(2) Is there a significant difference between the experimental group students who carried out the digital game development study and the control group students who continued the traditional method in terms of attitude values towards the English course?

(3) Is there a significant difference between the students who are engaged in digital game development and the control group students who continue the traditional method in terms of attitude values towards computer-aided teaching?

(4) What are the experimental group students' opinions about the innovative application in which digital game design studies are carried out?

In an environment where technology is widely used, individuals in today's world, do not have problems with the simple use of technology. That said, there are problems in using technology in a useful fashion (Davies, 2011). Bearing in mind he experiences of students who are 
preparing for the professions of the future, using technology, and also producing products with technological devices are of great importance in terms of being ready for these professions in a qualified manner.

Beatty (2010) stated that constantly renewed computer technologies offer important opportunities in finding innovative ways of teaching and learning languages. However, existing games in education and training environment may be inadequate from time to time. In this case, children with wide imagination can be active in designing new games (Özmutlu, 2018). Thus, children can be switched from digital consumer role to digital producer role. When the studies in the past are examined, it is observed that the students provide experiences over ready digital content. There is a quantitative and qualitative inadequacy of the studies in the literature at the secondary school level concentrating upon students who design their own educational digital content.

This study aims to make an important contribution to the literature with an innovative perspective in terms of studying students designing their own digital educational materials.

\section{Method}

\section{Research design}

In this study, a mixed research model, which is frequently encountered in social sciences, where qualitative and quantitative data are collected from the participants and the data are used for the same purpose, was used (Green, Krayder,\& Meyer, 2005). Creswell (2015) stated in his book that it is an important advantage for the researcher to draw conclusions by analyzing the collected data, both quantitatively (closed-ended) and qualitatively (open-ended), to analyze the research problems. Qualitative data collected about the study can provide detailed descriptive information about the application.

In the study, "Semi-Experimental Pattern Model with Pretest-Posttest Control Group" was used. The students were divided into two as the experimental group where the innovative application is performed and the control group where the traditional application continues. In the studies carried out with this method, the participants are subjected to measurements related to dependent variables before and after the application (Gündoğdu \& Korucu, 2018). The independent variables of the research are the practice and traditional teaching method in which the students develop their own digital games within the course. Dependent variables of the research are academic achievement level within the unit, attitude level towards primary school English lesson and attitude level towards computer assisted education.

\section{Study group of the research}

In this study, the sample is the secondary school students studying in a public school in Doğanhisar district of Konya province in 2019-2020 academic year. The distribution of the students participating in the study by gender is shown in Table 1. 
Table 1. Distribution of students participating in the study by gender

\begin{tabular}{llll}
\hline \multirow{2}{*}{ Gender } & Group & Total \\
\cline { 2 - 4 } & Experimental Group & Control Group & 21 \\
\hline Male & 11 & 10 & 13 \\
Female & 6 & 7 & 34 \\
Total & 17 & 17 & \\
\hline
\end{tabular}

When Table 1 is examined, it is seen that the two groups are numerically equal and the ratios of gender variables within the classroom are close to each other.

\section{Instrumentation}

\section{Academic achievement tests}

In the study, 20-question achievement tests were carried out for the experimental and control group students to measure their academic success within the scope of the "My Daily Routines" unit and the "Health" unit, which are the curriculum subjects of the English course. In academic achievement tests, each question has been prepared with 4 options. The created academic achievement tests were examined by the experts of the field before the study, afterwards corrections were made according to the feedback and they took the final form for the study.

The academic achievement test developed within the scope of the "My Daily Routines" unit was applied to 70 students who completed the same subject, the data obtained results were evaluated in the SPSS (Statistical Package for the Social Sciences) package program and the confidence interval was determined to be 0.777 .In the analysis, KR-2O test value was calculated as 0.78 for the internal consistency of the reliability test, since no students left a question blank in the test and the scoring values of the questions are equal. This value shows that the internal consistency of the test is high. The achievements determined within the scope of the academic achievement test developed for the "My Daily Routines" unit are shown in Table 2.

Table 2. My daily routines unit academic achievement test learning outcomes table

\begin{tabular}{lll}
\hline No & Learning Outcomes & $\begin{array}{l}\text { Number of } \\
\text { questions }\end{array}$ \\
\hline 1 & $\begin{array}{l}\text { Students will be able to understand specific information in short, oral texts } \\
\text { about daily routines. }\end{array}$ & 7 \\
2 & $\begin{array}{l}\text { Students will be able to understand the time. } \\
\text { Students will be able to understand short and simple written texts about daily } \\
\text { routines. }\end{array}$ & 5 \\
\hline
\end{tabular}

Achievement tests difficulty analysis results are between 0 and 1.0 indicates that the test is very easy and 1 indicates that it is very difficult. A result of 0.5 indicates that the test is at a normal level. The academic achievement test difficulty test value, which was developed for the "My Daily Routines" unit and used as a pre-test and post-test, was calculated as 0.52 . This indicates that the test in question is of normal difficulty.

For the second unit, "Health", the test results applied to 70 students who completed the subject were evaluated and the confidence interval was found to be 0.873.In the analysis, the 
KR-2O test value was calculated as 0.865 for the internal consistency of the reliability test, since no students left a question blank and the scoring values of the questions are equal in the test. This value shows that the internal consistency of the test is high. The achievements determined within the scope of the academic achievement test developed for the "Health" unit are shown in Table 3.

Table 3. Health unit academic achievement test learning outcomes table

\begin{tabular}{lll}
\hline No & Learning Outcomes & $\begin{array}{l}\text { Number } \\
\text { questions }\end{array}$ \\
\hline 1 & $\begin{array}{l}\text { Students will be able to identify common illnesses and understand some of the } \\
\text { suggestions made. }\end{array}$ & 6 \\
2 & $\begin{array}{l}\text { Students will be able to understand simple suggestions concerning illnesses. } \\
\text { Students will be able to understand short and simple texts about illnesses, }\end{array}$ & 6 \\
3 & needs and feelings
\end{tabular}

Academic achievement test difficulty test value, which was developed for the "Health" unit and used as a pre-test and post-test, was calculated as 0.542 . This indicates that the test in question is of normal difficulty.

\section{Attitude scale for elementary English course}

In this study, "Attitude Scale for Elementary English Course" developed by Baş (2012) was used. As a result of examining the attitudes towards the English lesson in the scale, five dimensions were presented as "sensitivity", "consciousness", "importance", methods and materials, "language and culture". The KMO value of the scale was 0.884 and the Bartlett test was 10134.161 ( $\mathrm{p}$ <.000).Reliability analysis, item-total correlation, Cronbach Alpha internal consistency coefficient and Spearman-Brown two semi test correlations were calculated, and the Cronbach Alpha reliability coefficient of the scale was found to be 0.92. Cronbach Alpha coefficients of other sub-dimensions of the scale were found to vary between 0.77 and 0.93. The two semi test correlations of the test were found to be 0.83.These results reveal that the overall scale and other sub-dimensions are also reliable. A significant relationship was observed at the level of 0.01 between the factors of the scale. This shows that all the factors of the scale are consistent with each other.5-point likert type was used in the scale. The scale consists of 27 items, 15 of which are positive and 12 of which are negative. For this reason, while scoring data to SPSS program reverse scoring was performed for 12 negative items.

\section{Computer assisted instruction evaluation scale}

In this application, "Computer Aided Teaching Evaluation Scale" developed by Dinçer and Doğanay (2016) was used. The scale consists of a total of 19 items. 5-point likert type was used in the scale. While preparing the measurement tool, the previously developed single-factor and 20-item Computer Aided Education Attitude Scale was taken as reference; however, all of the scale development steps were repeated again, as the measurement tool sample and some expressions changed. Studies of the first version and second version of the measuring tool were analyzed by explanatory factor analysis and then tested by the obtained scale confirmatory factor analysis. The level of participation of the student in the relevant scale item was arranged as "I strongly agree", "I agree", "I am indecisive", "I disagree", "I strongly disagree". These levels are rated as Strongly Agree $=5$, Agree $=4$, Undecided $=3$, Disagree $=2$, Strongly Disagree $=1$. The researcher who developed the scale mentioned that the negative expressions found in the original of the scale were translated into positive 
expressions because the students could not encode these expressions, and stated that a singlefactor measurement tool with 19 items was obtained by subtracting one item from the scale. In the explanatory factor analysis, it was determined that the confirmatory factor analysis values for this measurement tool, whose internal reliability coefficient was calculated as 0.89 , remained within the limit-acceptance values.

\section{Semi-structured interview form}

The linguistic control of the semi-structured interview form consisting of 10 openended questions developed to support the quantitative data acquired within the scope of the application with qualitative data was checked and the content of the questions was checked by the field experts.

In order to check the reliability of the qualitative data obtained, the codes created in accordance with the researcher data were compared with the codes of the two field experts. As a result of the individual coding carried out for the research data by the two field experts, final adjustments were made within the framework of the researcher's opinions. The consistency of the coding performed by the researcher and the experts independently of each other was determined by marking as "Similar opinion" or "Different opinion". In the event of an expert's contradiction, the process was carried out taking the opinion of the other expert. Reliability of data analysis in line with these processes was evaluated with the formula [Similar opinion / (Similar opinion + Different opinion) x 100] (Miles \& Huberman, 1994).The average reliability among coders for this study was found to be \%85.Information on the analysis of the qualitative data obtained under the heading of data analysis is presented.

\section{Collection of data}

\section{Pre-study preparations}

Before the study, practise was made with the students of the experimental group on the use of the block-based programming tool Scratch for approximately 1 month. Thus, the experimental group students gained experience creating content with the Scratch program before the study. The control group students continued their information technology and software curriculum.

In the information technology class where there are 17 student computers and 1 teacher computer, a sitting plan has been arranged so that there is one student per computer. The information technology teacher guided the English language teacher in using the information technology class during the experiment. In addition, preliminary information about the use of block-based programming tool is provided. The concerns of the English language teacher about transferring the English language curriculum subjects with the block-based programming tool were touched upon.

The timing of the study was arranged according to the annual plan prepared within the scope of the secondary school English curriculum. Before the implementation, the academic success levels and attitudes of the experimental group and the control group were measured as pretests.

Before the study, "My Daily Routines" unit and "Health" unit academic achievement tests, attitude scale towards elementary English course and evaluation scale for computer-aided 
education were applied to students as a pre-test. Independent Samples T-Test results for unrelated samples are shown in Table 4, Table 5, Table 6 and Table 7.

Table 4. Experimental and control group values as a result of academic achievement pretest practice within the scope of my daily routines unit

\begin{tabular}{|c|c|c|c|c|c|c|c|}
\hline & Groups & $\mathrm{N}$ & $\overline{\mathrm{x}}$ & Ss & $S d$ & $\mathrm{t}$ & $p$ \\
\hline \multirow[t]{2}{*}{ Pretest } & $\begin{array}{l}\text { Experimental } \\
\text { Group }\end{array}$ & 17 & 33.82 & 16.91 & \multirow[t]{2}{*}{31.99} & \multirow[t]{2}{*}{45} & \multirow[t]{2}{*}{.68} \\
\hline & Control Group & 17 & 31.17 & 17.00 & & & \\
\hline
\end{tabular}

$* \mathrm{p}<0.05$

Table 5. Experimental and control group values as a result of academic achievement pretest practice within the scope of health unit

\begin{tabular}{llllllll}
\hline & Groups & $\mathrm{N}$ & $\overline{\mathrm{x}}$ & $\mathrm{Ss}$ & \multicolumn{1}{c}{$S d$} & $\mathrm{t}$ & $p$ \\
\hline \multirow{3}{*}{ Pretest } & $\begin{array}{l}\text { Experimental } \\
\text { Group }\end{array}$ & 17 & 25.58 & 9.16 & \multirow{2}{*}{29.63} & \multirow{2}{*}{-.63} & \multirow{2}{*}{.11} \\
\cline { 2 - 6 } & Control Group & 17 & 27.94 & 12.25 & & & \\
\hline
\end{tabular}

$* \mathrm{p}<0.05$

Table 6. Experimental group and control group pretest results in terms of attitude values for English course

\begin{tabular}{|c|c|c|c|c|c|c|c|}
\hline & Groups & $\mathrm{N}$ & $\overline{\mathrm{x}}$ & Ss & $S d$ & $\mathrm{t}$ & $p$ \\
\hline \multirow[t]{2}{*}{ Pretest } & $\begin{array}{l}\text { Experimental } \\
\text { Group }\end{array}$ & 17 & 99.82 & 23.10 & \multirow[t]{2}{*}{31.99} & \multirow[t]{2}{*}{.047} & \multirow{2}{*}{.42} \\
\hline & Control Group & 17 & 96.41 & 18.70 & & & \\
\hline
\end{tabular}

*p $<0.05$

Table 7. Experimental group and control group pretest results in terms of attitudes towards computer assisted instruction

\begin{tabular}{llllllll}
\hline & Groups & $\mathrm{N}$ & $\overline{\mathrm{x}}$ & $\mathrm{Ss}$ & $\mathrm{Sd}$ & $\mathrm{t}$ & $p$ \\
\hline \multirow{3}{*}{ Pretest } & $\begin{array}{l}\text { Experimental } \\
\text { Group }\end{array}$ & 17 & 63.82 & 9.91 & & & \\
\cline { 2 - 6 } & Control Group & 17 & 63.64 & 11.49 & & .048 & .38 \\
\hline
\end{tabular}

$* \mathrm{p}<0.05$

When Table 4, Table 5, Table 6 and Table 7 are examined, academic achievement values and values obtained from attitude scales are close to each other in the experimental and control groups. No significant difference was observed between the results. Academic success and attitude values of both groups were similar before the study.

Practices within the scope of my daily routines unit with experimental group students (1-4 weeks)

In order to create their own daily scenarios with the block-based programming tool, students first acquired images that can explain their clock routines and daily routines from the internet. Then they transferred these pictures to their works. Information technologies teacher and English teacher guided the students in the process of using block-based programming tools.

After the work of the first unit is completed in a 4-week period, the students shared their scenarios with the English lesson teacher and get feedback. Within the scope of volunteering, 
they examine each other's work. Finally, the academic achievement posttest is applied to both groups within the scope of the relevant unit.

\section{Practices within the scope of health unit with experimental group students (4-8 weeks)}

Experimental group students were asked to create a hospital game with block-based programming tool. They were asked to find the doctor and patient images they would use in the hospital game by using the internet. It is also stated that they can help each other in the study process in order to increase the communication of the students with each other and to work in cooperation. It was observed that the students were in communication with each other during the experiment.

The students were asked to put themselves in the role of a doctor after adding and editing the hospital game images to the block-based programming tool. The English language teacher asked what the patient images meant by the students in their own games. The students were asked to discuss the questions that should be asked to the patients as a doctor. Opinions were taken and the sentences approved by the teacher were added to the block-based programming tool by the students, with a speech bubble above the characters.

Free time is allocated for students to play their games and interact with each other. At the end of the study, the academic achievement test and attitude scales related to the "Health" unit were applied as posttest. In addition, a semi-structured interview form, in which qualitative data was obtained, was applied.

\section{Data analysis}

For the analysis of the pretest and posttest quantitative data obtained during the study, the statistical analyzes in the SPSS statistics program will be used. The dependent variable is continuous. Independent variables are categorical. The variances are homogeneous. They do not contain outliers. These situations show that the necessary assumptions are met to report the T-test results (Arslan, 2018). Since the number of participants per group was less than 20 and the number of observations was less than 50, a normality test was conducted before the application. In the normality test results, Shapiro-Wilk test value was observed above 0.05. This situation indicates that the variables do not deviate significantly from the normal distribution. For this reason, t-test applications were carried out (Aras, Akça, \& Akalan, 2013). Independent groups t-test was used to test whether there was a significant difference between the pretest and posttest scores within the experimental and control groups, as well as in the posttest comparisons between the groups. The significance level was accepted as .05 to make interpretations on the analysis data obtained as a result of the applications.

The ANCOVA test assumptions were examined to reveal whether there was a significant difference between the posttest scores of the tests developed to measure the academic achievement of the experimental and control groups within the scope of "My Daily Routines" and "Health" units. Within the scope of the study, standard errors of Skewness (0.652 for health unit, 0.635 for my daily routines unit) and Kurtosis ( -0.078 for health unit, $-0,194$ for my daily routines unit values were examined in order to control the normality values of the academic achievement test data belonging to the "health" and "My Daily Routines" units developed to measure academic achievement. Histograms were suitable for normal distribution. Since the data in the Detrended table is randomly distributed, this situation points to conformity to normal distribution. 
Within the scope of the study, the standard errors of Skewness (0.330 in the data obtained for computer aided attitudes, 0.291 in the data obtained for attitudes towards the English course) and Kurtosis $(-0.282$ in the data obtained for computer aided attitudes, 0.574 in the data obtained for attitudes towards the English course) values were examined in order to control the normality values of the data obtained from the scales applied to measure the attitudes towards computer-aided teaching and attitudes towards the English course. Histograms are suitable for normal distribution. Since the data in the Detrended table is randomly scattered, it points to conformity to normal distribution. In addition, as the values of the Shapiro-Wilk test in the data obtained for computer-aided instruction were higher than 0.05 , it indicates a normal distribution (Özer, 2007). The answers given by the experimental group in the semistructured interview form at the end of the application were analyzed by the content analysis method. In the content analysis, similar data were gathered within the framework of certain categories, main themes and sub-themes, and this category, main theme and sub-themes were understandably interpreted and reported. During the analysis phase, the following processes were followed (Yıldırım \& Şimşek, 2008);

(1) Data coding process

(2) Finding suitable themes

(3) The process of organizing and defining the data according to their codes and themes

(4) Interpretation of the findings

\section{Findings}

\section{Findings related to the first research question}

My daily routines unit experimental group pretest-posttest comparison

Table 8. Experimental group pretest-posttest comparison results for my daily routines unit

\begin{tabular}{llllllll}
\hline & Tests & $\mathrm{N}$ & $\overline{\mathrm{x}}$ & $\mathrm{Ss}$ & $S d$ & $\mathrm{t}$ & $p$ \\
\hline $\begin{array}{l}\text { Experimental } \\
\text { Group }\end{array}$ & Pretest & 17 & 33.82 & 16.91 & \multirow{2}{*}{29.53} & \multirow{2}{*}{-4.06} & \multirow{2}{*}{14} \\
\cline { 2 - 7 }$* 0.05$ & Posttest & 17 & 61.76 & 22.77 & & & \\
\hline${ }_{\mathrm{p}<0.05}$ & & & & & &
\end{tabular}

When the academic achievement pre-test post-test scores of the experimental group in the unit "My Daily Routines" were compared with the independent groups t-test (pre-test average $\overline{\mathrm{x}}=$ 33.82; post-test average $\overline{\mathrm{x}}=61.76$ ) it was determined that experimental group students increased their academic achievement as a result of the digital content design and game development study in which they participated (Table 8).

When the pre-test and post-test scores of the control group in the academic achievement test for the "My Daily Routines" unit were compared (pre-test mean $\overline{\mathrm{x}}=31.17$; post-test mean $\overline{\mathrm{x}}=$ 45.58), no statistically significant difference was observed ( $p<0.05)$. However, it was determined that the control group students increased their academic success. 
Health unit experimental group pretest-posttest comparison

Table 9. Experimental group pretest-posttest comparison results for health unit

\begin{tabular}{|c|c|c|c|c|c|c|c|}
\hline & Tests & $\mathrm{N}$ & $\overline{\mathrm{x}}$ & Ss & $S d$ & $\mathrm{t}$ & $p$ \\
\hline \multirow{2}{*}{$\begin{array}{l}\text { Experimental } \\
\text { Group }\end{array}$} & Pretest & 17 & 25.58 & 9.16 & \multirow{2}{*}{28.01} & \multirow{2}{*}{-8.56} & \multirow{2}{*}{.041} \\
\hline & Posttest & 17 & 59.70 & 13.63 & & & \\
\hline
\end{tabular}

When the academic achievement test pretest and posttest scores for the "Health" unit of the experimental group were examined (pretest mean $\overline{\mathrm{x}}=25.58$; posttest mean $\overline{\mathrm{x}}=59.70$ ) statistical significance level was calculated as $\mathrm{p}=041$.For this application, the result was observed significantly $(\mathrm{p}<0.05)$.In addition, it was determined that they increased their academic success as a result of the digital content design and game development study participated by the experimental group students (Table 9).

When the pre-test and post-test scores of the control group in the academic achievement test for the "Health" unit were compared (pre-test mean $\overline{\mathrm{x}}=27.94$; post-test mean $\overline{\mathrm{x}}=40.58$ ), no statistically significant difference was observed $(\mathrm{p}<0.05)$. However, it was determined that the control group students increased their academic success.

\section{Experimental and control group post-test comparison for my daily routines unit}

Table 10. Experimental and control group post test comparison for my daily routines unit

\begin{tabular}{|c|c|c|c|c|c|c|c|c|}
\hline & Groups & $\mathrm{N}$ & $\overline{\mathrm{x}}$ & Ss & $S d$ & $\mathrm{t}$ & $p$ & $\eta 2$ \\
\hline \multirow[t]{2}{*}{ Posttest } & $\begin{array}{l}\text { Experimental } \\
\text { Group }\end{array}$ & 17 & 61.76 & 22.77 & \multirow[t]{2}{*}{27.21} & \multirow[t]{2}{*}{2.46} & \multirow[t]{2}{*}{.048} & \multirow[t]{2}{*}{.84} \\
\hline & Control Group & 17 & 45.58 & 14.56 & & & & \\
\hline
\end{tabular}

*p $<0.05$

In order to reveal whether there is a significant difference between the posttest scores of the control and experimental groups within the scope of the "My Daily Routines" unit, it was first checked whether the assumptions of ANCOVA were violated. In this context, whether the difference between the slopes of the regression lines between the groups is significant or not was examined with the "group $\mathrm{x}$ pretest" joint effect test and it was concluded that the difference was statistically significant. With this result, since the related assumption of ANCOVA was violated, whether there was a significant difference between the posttest scores of the groups was examined with the Unrelated Samples t-Test instead of ANCOVA.

When the significance level of $* \mathrm{p}<.05$ was examined in the posttests performed for the first unit, the experimental and control groups after the application, it was found to be $.048<.05$. The result is meaningful for this application. In addition, in post-test comparisons (experimental group post-test mean $\bar{x}=61.76$; control group post-test mean $\bar{x}=45.58$ ), the post-test scores of the experiment group were higher (Table 10). The effect size value of digital content design and game development on academic achievement was calculated as $\eta 2$ $=.84$.In this case, it can be said that the digital content design and game development study has a significant positive effect size on the academic success for the first unit in the experimental and control group comparisons in terms of posttest academic achievement tests. 


\section{Experimental and control group post test comparison for health unit}

ANCOVA assumptions were observed to reveal whether there was a significant difference between the posttest scores of the tests developed to measure the academic achievement of the experimental and control groups within the scope of the "Health" unit. In this context, whether the difference between the slopes of the regression lines between the groups is significant or not was examined with the "group * pretest" common effect test. There was no statistically significant difference $(\operatorname{sig}(\mathrm{p})=0.767)$. The fact that there is a linear relationship between the academic achievement pre-test and post-test scores for both units and the Pearson correlation coefficient $(r=.46)$ has shown that a significant difference between the academic achievement pre-test and post-test scores can be controlled by ANCOVA (Divarc1 and Saltan, 2017). The data regarding the covariance analysis are given in Table 11 and Table 12.

Table 11. Groups' actual post-test scores and post-test scores corrected according to pre-test scores

\begin{tabular}{llllll}
\hline & \multicolumn{3}{c}{ Posttest } & \multicolumn{2}{c}{ Corrected Posttest } \\
\hline Groups & $\mathrm{N}$ & $\overline{\mathrm{x}}$ & $\mathrm{Ss}$ & $\overline{\mathrm{x}}$ & $\mathrm{Ss}$ \\
\hline Experimental Group & 17 & 59.70 & 13.63 & 78.23 & 9.91 \\
Control Group & 17 & 40.58 & 15.99 & 34.70 & 11.49 \\
\hline
\end{tabular}

ANCOVA was performed with posttest scores corrected according to the pre-test scores shown in Table 11. The results of ANCOVA are shown in Table 12.

Table 12. ANCOVA results of posttest scores corrected according to the groups' pretest scores

\begin{tabular}{|c|c|c|c|c|c|c|}
\hline Source of Variance & $\begin{array}{l}\text { Sum of } \\
\text { Squares }\end{array}$ & $\mathrm{Sd}$ & $\begin{array}{l}\text { Mean } \\
\text { Square }\end{array}$ & $\mathrm{F}$ & $\mathrm{p}$ & $\eta 2$ \\
\hline $\begin{array}{l}\text { Pre- } \\
\text { Test(Regression) }\end{array}$ & 106.71 & 1 & 106.71 & .47 & .000 & \\
\hline Groups(Posttest) & 43.85 & 1 & 43.85 & .11 & .000 & 1.28 \\
\hline Error & 7013.87 & 31 & 226.25 & & & \\
\hline Corrected Total & 23226.47 & 33 & & & & \\
\hline
\end{tabular}

When the results were analyzed, it was observed that the digital content design and game development study was in favor of the experimental group. The effect size of digital content design and game development on academic achievement was calculated as $\eta 2=1$.28. In this case, it can be said that the digital content design and game development study has an effective positive effect size for the second unit in the experimental and control group comparisons in terms of posttest academic achievement tests.

\section{Findings related to the second research question}

\section{Experimental group pretest posttest comparison for attitudes towards English course}


Table 13. Experimental group pretest posttest comparison of attitudes towards English course

\begin{tabular}{|c|c|c|c|c|c|c|c|}
\hline & Tests & $\mathrm{N}$ & $\overline{\mathrm{x}}$ & Ss & $S d$ & $\mathrm{t}$ & $p$ \\
\hline \multirow{2}{*}{$\begin{array}{l}\text { Experimental } \\
\text { Group }\end{array}$} & Pretest & 17 & 99.82 & 23.10 & \multirow{2}{*}{23.76} & \multirow{2}{*}{-1.32} & \multirow{2}{*}{.020} \\
\hline & Posttest & 17 & 108.17 & 11.75 & & & \\
\hline
\end{tabular}

When the pre-test and post-test scores of the experimental group's attitudes towards the English course were compared (pretest average $\overline{\mathrm{x}}=99.82$; posttest average $\overline{\mathrm{x}}=108.17$ ), statistically, since it is $0.020<.05 * \mathrm{p}<.05$ significant for the level of significance a difference was observed ( $\mathrm{p}<0.05)$. As a result of the digital content design and game development study participated by the experimental group students, it was determined that they increased their attitudes towards the English course (Table 13).

When the pre-test and post-test scores of the control group's attitudes towards the English course were compared (pre-test average $\overline{\mathrm{x}}=96.41$; post-test average $\overline{\mathrm{x}}=92.41$ ), no statistically significant difference was observed $(p<0.05)$. Since the difference between the post-test and pre-test results is negative, it is seen that the attitudes of the control group students towards the traditional English lesson have decreased during the application.

Post-test comparison of experimental and control group students' attitudes towards English lessons

Table 14. Post-test comparison of experimental and control group students' attitudes towards English lessons

\begin{tabular}{lllllllll}
\hline & Groups & $\mathrm{N}$ & $\overline{\mathrm{x}}$ & $\mathrm{Ss}$ & $\mathrm{Sd}$ & $\mathrm{t}$ & $p$ & $\eta 2$ \\
\hline \multirow{3}{*}{ Posttest } & $\begin{array}{l}\text { Experimental } \\
\text { Group }\end{array}$ & 17 & 108.17 & 11.75 & & & & \\
\cline { 2 - 6 } & Control Group & 17 & 92.41 & 19.97 & & 2.90 & .048 & .45 \\
\hline
\end{tabular}

*p $<0.05$

After the application, when the significance level of $* \mathrm{p}<.05$ was examined in the posttests conducted to measure the attitudes of the experimental and control groups towards the English course, it was found to be $.048<.05$.A meaningful result has been observed for this application. In posttests (experimental group posttest mean $\overline{\mathrm{x}}=108.17$; control group posttest mean $\overline{\mathrm{x}}=92.41)$, it was observed that the posttest points of the experimental group were higher (Table 14).

When the experimental group pretest and posttest comparisons of the digital content design and game development study were examined, the effect size values on attitudes towards the English course were calculated as $\eta 2=.45$. In this case, it can be said that the study of digital content design and game development has a moderate positive effect size on students' attitudes towards English lesson. 


\section{Findings related to the third research question}

\section{Experimental group pretest posttest comparison in terms of attitudes towards computer assisted instruction}

Table 15. Experimental group pretest posttest comparison of attitudes towards computer assisted instruction

\begin{tabular}{|c|c|c|c|c|c|c|c|}
\hline & Tests & $\mathrm{N}$ & $\overline{\mathrm{x}}$ & Ss & $S d$ & $\mathrm{t}$ & $p$ \\
\hline \multirow{2}{*}{$\begin{array}{l}\text { Experimental } \\
\text { Group }\end{array}$} & Pretest & 17 & 63.82 & 9.91 & \multirow{2}{*}{28.49} & \multirow{2}{*}{-1.81} & \multirow{2}{*}{.042} \\
\hline & Posttest & 17 & 71.47 & 14.29 & & & \\
\hline
\end{tabular}

${ }^{*} \mathrm{p}<0.05$

When the pre-test and post-test scores of the experimental group's attitudes towards computer-assisted teaching (pretest mean $\overline{\mathrm{x}}=63.82$; posttest mean $\overline{\mathrm{x}}=71.47$ ) were statistically, $.042<.05$ for $* \mathrm{p}<.05$ significance level a significant difference was observed ( $\mathrm{p}$ $<0.05)$.As a result of the digital content design and game development study that the experiment group students participated, it was determined that they increased their attitudes towards the English course (Table 15).

When the pre-test and post-test scores of the control group's attitudes towards computer-aided instruction were compared (pre-test mean $\overline{\mathrm{x}}=63.64$; post-test average $\overline{\mathrm{x}}=64.47$ ), no statistically significant difference was observed $(\mathrm{p}<0.05)$. Since the post-test and pre-test results are very close to each other, the control group students' attitudes towards computeraided teaching are close to each other during the application that they continue with the traditional method.

Post-test comparison of experimental and control group students' attitudes towards computer assisted instruction

Table 16. Post-test comparison of experimental and control group students' attitudes towards computer assisted instruction

\begin{tabular}{lllllllll}
\hline & Groups & $\mathrm{N}$ & $\overline{\mathrm{x}}$ & $\mathrm{Ss}$ & $\mathrm{Sd}$ & $\mathrm{t}$ & $p$ & $\eta 2$ \\
\hline \multirow{3}{*}{ Posttest } & $\begin{array}{l}\text { Experimental } \\
\text { Group }\end{array}$ & 17 & 71.47 & 14.29 & & & & \\
\cline { 2 - 7 } & Control Group & 17 & 64.47 & 9.07 & & 1.70 & .044 & .62 \\
\hline
\end{tabular}

$* \mathrm{p}<0.05$

After the study, when the significance level of $* \mathrm{p}<.05$ was examined in the posttests conducted to measure the attitudes of the experimental and control groups towards computeraided teaching, it was found that $.044<.05$. A meaningful result has been observed for this application. In posttests (experimental group posttest mean $\overline{\mathrm{x}}=71.47$; control group posttest mean $\bar{x}=64.47)$, it was observed that the posttest scores of the experimental group were higher (Table 16).

The effect size values of the digital content design and game development study on the attitudes towards computer-aided teaching have been calculated as $\eta 2=.62$ within the framework of the experimental group pre-test post-test values. In this case, it can be said that digital content design and game development work has a moderate positive effect size on students' attitudes towards computer-aided teaching. 


\section{Findings related to the fourth research question}

The fourth research question of the study was:"What are the experimental group students' opinions about the innovative application in which digital game design studies are carried out?" to answer this question, the table created by coding the answers given by the students in the semi-structured interview form is shown in Table 17 in categories.

Table 17. Opinions about designing games in English with block based application

\begin{tabular}{|c|c|c|c|c|}
\hline Categories & Main Themes & Sub-themes & $\begin{array}{l}\text { Yes } \\
\text { n (Frequency) }\end{array}$ & $\begin{array}{l}\text { No } \\
\mathrm{n} \\
\text { (Frequency) }\end{array}$ \\
\hline \multirow{4}{*}{ Content } & \multirow{3}{*}{ Application usage } & It was useful & 6 & 3 \\
\hline & & $\begin{array}{l}\text { More difficult activities could be } \\
\text { done }\end{array}$ & 1 & \\
\hline & & $\begin{array}{l}\text { It made me understand English } \\
\text { lesson better }\end{array}$ & 9 & 3 \\
\hline & Other & $\begin{array}{l}\text { It would be better if it was done for } \\
\text { another lesson }\end{array}$ & 2 & \\
\hline Technical & Application time & My time wasn't enough & 1 & \\
\hline \multirow{4}{*}{ Effect } & \multirow{3}{*}{$\begin{array}{l}\text { Attitude } \\
\text { practice }\end{array}$} & $\begin{array}{l}\text { Likewise, it can be done in other } \\
\text { courses }\end{array}$ & 5 & \\
\hline & & The application was fun & 4 & 1 \\
\hline & & $\begin{array}{l}\text { My interest in English lessons } \\
\text { increased }\end{array}$ & 5 & 2 \\
\hline & Other & Designing a game was easy & 3 & 3 \\
\hline
\end{tabular}

In the study, with the block-based programming tool, the responses regarding the opinions on the game design were coded and three categories were created as "Content", "Technical" and "Effect". Main and sub-themes were created under these categories.

Of the sub-themes determined for the main theme of application use in the content category, it was useful $=6$, not useful $=3$, more difficult activities could be done $=1$, it made me better understand the English lesson $=9$, no it did not make me understand the English lesson = 3.Under the other main theme, it would be better if it was done for another lesson $=2$.

Under the main theme of the application time in the technical category, my time was not enough $=1$.

In the impact category, sub-themes determined under the main theme for application likewise, it can be done in other courses $=5$, the application was fun $=4$, the application was not fun $=$ 1, it increased my interest in the English lesson = 5, it did not increase my interest in the English lesson $=2$. Of the sub-themes determined for the other main theme, it was easy to design a game $=3$, not easy $=3$.

Some of the answers given about the likes and dislikes of designing English games with block based application are as follows:

"It's very complicated I don't like it. I do not like English lessons because I am not interested." (EG-1).

"It was a little complicated and difficult. My English is not good, I would like to do it for mathematics." (EG-2). 
"This app was much better with English and I learned better." (EG-7).

"My interest in English lessons increased more. I understood English words more easily. I wish I could make more difficult games for the other lessons ."(EG-9).

"It was an application that I enjoyed. I learned English words. It made me understand English better. I wish we could do it for math. I had a lot of fun and learned well " (EG-10).

\section{Discussion and conclusion}

Within the scope of the first unit "My Daily Routines", when the academic achievement pre-test and post-test scores of the experimental group were examined, it was determined that they increased their academic success after digital content design and game development studies. However, no significant difference was observed. Taking into account the reasons for the absence of a significant difference, it can be considered that the knowledge of the use of block-based programming tools, which students learned in a short period of 1 month in the 5th grade, is not sufficient for implementation. As a matter of fact, qualitative findings obtained from the experimental group students show that students encounter technical problems from time to time. These reasons may have influenced motivations for implementation. Considering the English lesson teacher at the same time, preliminary knowledge of the trainer for practice is important, as mentioned in Armknecht's (2015) study. Various problems experienced by the educator during the adaptation process to computer assisted instruction may have affected his motivation. However, if we look at the posttest comparisons of the experimental group and the control group in terms of academic achievement tests in the activity for the first unit, a significant difference was observed.

A significant difference was observed when the experimental group was evaluated as a pretest and a post-test in terms of academic success regarding the activity carried out within the scope of the "Health" unit, which is the second unit of the study. It was determined that the experimental group students increased their academic success as a result of digital content design and game development study. It can be thought that the experiences that students obtained in the study for the previous unit benefited from the study for the second unit.

For the second unit "Health", if we look at the post-test comparisons of the experimental group and the control group, no significant difference was observed. Chen, Liu, and Shou (2018) and Huizenga, Admiraal, Ten Dam, and Voogt (2019) pointed out the element of competition among students. They stated that this situation caused negative consequences in terms of implementation results. In fact, negative competitive situations were observed amongst students during the practice and efforts were made to focus students on the process by interfering with these situations.

A significant difference was observed when the results of the experimental group in terms of attitudes towards English lesson were evaluated as pretest and posttest. As a result of the digital content design and game development study in which the experimental group students participated, it was determined that they increased their positive attitudes towards the English course. If we look at the post-test comparisons of the experimental group and the control group, a significant difference was observed again. As stated in the study of Glushkova (2016), the game showed positive effects on learning motivations and positively affected attitudes towards the lesson. Thus, it was seen that the innovative method gave positive results within the framework of the attitudes towards the English lesson for the experimental group students.

A significant difference was observed when the results of the experimental group in terms of 
attitudes towards computer assisted instruction were evaluated as pretest and posttest. As a result of the digital content design and game development study in which the experimental group students participated, it was determined that they increased their attitudes towards computer aided education. If we look at the post-test comparisons of the experimental group and the control group, a significant difference was observed again. As Hüseyin, Ow, Cheong, Thong, and Ebrahim (2019) mentioned in the meta-analysis study, computer-aided teaching practices had positive effects on understanding the content. In this study, when students' opinions about designing educational games with block-based programming tool were examined, students stated that their interest increased thanks to the applications. At the same time, they expressed their opinions on the fact that they found the application of game design useful to better understand the subjects of the English lesson (Table 17).Considering the aforementioned situations, the positive experiences that the innovative method brought to the students of the experimental group positively affected the attitudes of the students towards computer-assisted teaching.

As a result of the study, if the evaluation is made for the first question of the research, the findings of the digital content design and game development studies and academic achievement of the experimental group students within the scope of the English course indicate the positive effects of the method. Also, in post-test comparisons, this method can enable us to obtain more beneficial results than traditional method in increasing motivation and learning of students.

Within the scope of the second research question, the pre-test and post-test results of the students in the experimental group reveal a significant difference in terms of attitudes towards elementary English lesson. In addition, the significant difference in favor of the experimental group in the post-test comparisons of the experimental and control groups shows that the digital content design and game development study is effective in creating positive attitudes towards the English course.

Within the scope of the third research question, the pre-test and post-test results of the experimental group students reveal a significant difference in terms of attitudes towards computer-aided teaching in the evaluation. In addition, the significant difference in favor of the experimental group in the post-test comparisons of the experimental and control groups shows that the digital content design and game development work is effective in creating positive attitudes towards computer-aided teaching.

Within the scope of the fourth research question, when the opinions of the students regarding digital content design and game development study are examined, the opinions stated within the framework of 10 sub-questions are generally positive. However, technical problems experienced from time to time, usage problems arising from the lack of practical knowledge and negative prejudices about the English course were expressed by the students.

When the evaluation is made within the scope of the basic research question, it is concluded that the innovative method used in this study is a beneficial application that will positively affect the academic achievement and attitudes of the students, provided that the necessary preparations are made for all stakeholders of the education.

\section{Suggestions}

The findings obtained from the data obtained as a result of the study showed the positive effect of digital content design and game development work in classroom 
environments. The application is extensible and can be tested in different environments, with different digital content creation tools and in different courses. Some suggestions have been made for more efficient work that can be carried out in the future;

- It is recommended to carry out studies that can increase the competence of students and teachers to develop digital content in schools.

- It is recommended that students who participate in the application are provided with the appropriate hardware infrastructure to develop digital content.

- It is recommended that teachers, who will apply digital content design and game development in their classes, to be prepared for the problems they may encounter before hand and to receive trainings prior to the application in order to implement an effective application.

- In order to achieve more meaningful results regarding academic achievements, it is recommended to pay attention to the competition factor as mentioned by Huizenga, Admiraal, Ten Dam, and Voogt (2019) and follow the process by the educator to minimize negative effects.

- Considering the qualitative data obtained from students, it is recommended to carry out more comprehensive studies on the use of the innovative method used in this study in different lessons.

\section{Acknowledgments}

This article was created from the master's thesis that the first author completed in Necmettin Erbakan University, Institute of Educational Sciences, Computer and Instructional Technologies Education under the supervision of the second author.

\section{References}

Akpınar, Y., \&Altun, A. (2014). Bilgi toplumu okullarında programlama eğitimi gereksinimi [Programming education requirement in Information Society schools]. Elementary Education Online, 13(1).

Alan, D. (2017). Digital Game-Based Learning Approach to Teach Software Development.(Doctoral dissertation, Selcuk University Institute of Science).

Aras, D., Akça, F., \& Akalan, C. (2013). 50 Metre Sprint Yüzmenin 13-14 Yaşlarındaki Erkek Yüzücülerde Kalp Hızı Değişkenliğine Etkisi [The Effect of 50 Meter Sprint Swimming on Heart Rate Variability in 13-14 Years Old Male Swimmers].

Armknecht, M. P. (2015). Case study on the efficacy of an elementary STEAM laboratory school (Doctoral dissertation, Lindenwood University).

Arslan, K. (2018, 21 Nisan). SPSS'de Bağımsız Örneklem T-Testi [Independent Sample TTest] [Web Günlük Postas1]. 7 Kasim 2020 tarihinde reached from https://www.galloglu.com/blog/bagimsiz-orneklem-t-test-SPSS-independent-sample-ttest

Beatty, K. (2010). Teaching and Researching Computer-Assisted Language Learning. London: Pearson Education Limited.

Baş, G. (2012). Attitude Scale for Elementary English Course: Validity and ReliabilityStudy.International Online Journal of Educational Sciences, 4(2).

Chen, C. H., Liu, J. H., \&Shou, W. C. (2018). How competition in a game-based science learning environment influences students' learning achievement, flow experience, and learning behavioral patterns. Journal of Educational Technology \& Society, 21(2), 164-176. 
Courville, K. (2011). Technology and Its Use in Education: Present Roles and Future Prospects. Online Submission.

Creswell, J. W. (2015). A concise introduction to mixed methods research.SAGE publications.

Davies, R. S. (2011). Understanding technology literacy: A framework for evaluating educational technology integration. TechTrends, 55(5), 45.

Dinçer, S., \&Doğanay, A.(2016). Bilgisayar Destekli Öğretimi Değerlendirme Ölçeği Uyarlama Çalışması [Computer Assisted Instruction Evaluation Scale Adaptation Study].Journal of OndokuzMayıs University Faculty of Education, 35(1), 45-62.

Divarc1, Ö. F., \& Saltan, F. (2017). Multimedya destekli probleme dayalı öğrenme yaklaşımının fen eğitiminde akademik başarıya ve tutuma etkisi [The effect of multimedia-supported problem-based learning approach on academic success and attitude in science education]. Ahi Evran Üniversitesi Kırşehir Eğitim Fakültesi Dergisi, 18(3), 91-104.

Glushkova, T. (2016).Application of block programming and game-based learning to enhance interest in computer science. Journal of Innovations and Sustainability, 2(1), 21-32.

Gülbahar, Y., Avc1, Ü.,\& Kalayc1, E. (2012). Learning by Doing: An Example Application of "Goal-Based Scenario" Approach. Education and Science, 37(165).

Gündoğdu, M. M., \&Korucu, A. T. (2018).The Effects of Collaborative Learning Developed with Blog Technology onReflecting Thinking Skills Towards Problem Solving and Motivation Levels and on Academic Success of Secondary School Students. Anadolu University Faculty of Education Journal, 2(3), 196-226.

Günkör, C. (2017). Exploration of the Relationship Between Education and Development, 3(1), 14-32.

Greene, J. C., Kreider, H., \& Mayer, E. (2005).Combining qualitative and quantitative methods in social inquiry. Research methods in the social sciences, 1, 275-282.

Huizenga, J., Admiraal, W., Ten Dam, G., \&Voogt, J. (2019). Mobile game-based learning in secondary education: Students' immersion, game activities, team performance and learning outcomes. Computers in Human Behavior, 99, 137-143.

Hussein, M. H., Ow, S. H., Cheong, L. S., Thong, M. K., \&Ebrahim, N. A. (2019). Effects of digital game-based learning on elementary science learning: A systematic review. IEEE Access, 7, 62465-62478.

Jennett, C., Papadopoulou, S., Himmelstein, J., Vaugoux, A., Roger, V., \& Cox, A. L. (2017). Case Study 3: Students' Experiences of Interdisciplinary Learning while Building Scientific Video Games. International Journal of Game-Based Learning (IJGBL), 7(3), 93-97.

Miles, M. B., \&Huberman, A. M. (1994). Qualitative data analysis: An expanded sourcebook. sage.

OECD. (2018). Education Policy in Japan: Building Bridges towards 2030, Reviews of National Policies for Education.

Özer, A. Y. (2007). Normallik testlerinin karşılaştırılması [Comparison of Normality Tests ] (Doctoral dissertation), Ankara University Science Graduate School Zootechny Department.

Özmutlu, M. (2018). Designing A Digital Game Design Platform For Children (Unpublished Master Thesis).

Prensky, M. (2003). Digital game-based learning. Computers in Entertainment (CIE), 1(1), 21-21.

Scholz, K. (2016). Online Digital Game-Based Language Learning Environments: Opportunities for Second Language Development. 
Subrahmanyam, K., \&Renukarya, B. (2015). Digital games and learning: Identifying pathways of influence. Educational psychologist, 50(4), 335-348.

Taşdemir, Ş., \&Şüyun, S. B. (2016).Computer Game Design and an Approach Intended to Gain Educationality to The Computer Game Design. Selçuk-Technical Journal, 15(2), 113-124.

Tokac, U., Novak, E., \& Thompson, C. G. (2019). Effects of game-based learning on students' mathematics achievement: A meta-analysis. J Comput Assist Learn, 1-14.

Whelan, D. L. (2005). Let the games begin. School Library Journal, 51(4), 40-43.

Yükseltürk, E., \&Altık, S. (2016). Investigation of pre-service information technology teachers' game projects prepared with Scratch. SDU International Journal of Educational Studies, 3(1), 59-66. 